\title{
PENGARUH KOMUNIKASI DAKWAH MAJELIS ULAMA INDONESIA TERHADAP KEPATUHAN UMAT ISLAM DI CINERE, DEPOK, JAWA BARAT DALAM MELAKSANAKAN FATWA-FATWA MUI YANG BERKAITAN DENGAN WABAH COVID-19
}

\author{
Dicky Salahuddin ${ }^{1)}$, Afrah Jamilah ${ }^{2)}$ \\ Institut Komunikasi dan Bisnis LSPR \\ Email: afrah.jamilah7@gmail.com
}

\begin{abstract}
ABSTRAK
Majelis Ulama Indonesia atau yang biasa disingkat dengan MUI didirikan pada tanggal 17 Rajab 1375 H bertepatan dengan tanggal 26 Juli 1975 M. Lembaga tersebut didirikan sebagai wadah musyawarah para ulama, zu'ama dan cendekiawan muslim dalam mengayomi umat dan mengembangkan kehidupan yang islami. Sebagai lembaga tertinggi yang menaungi ulama dan cendikiawan muslim di Indonesia, MUI merespon dengan cepat banyak fenomena yang muncul di Indonesia, seperti wabah covid-19, dengan mengeluarkan tujuh fatwa yang terkait dengan ibadah saat wabah covid-19. Walaupun sudah ada fatwa MUI yang berhubungan pencegahan covid-19, namun belum sepenuhnya dipatuhi oleh umat Islam Indonesia, khususnya umat Islam di Depok. Depok menjadi objek penelitian karena Depok merupakan penyumbang kasus positif covid-19 tertinggi di Jawa Barat. Penelitian ini bertujuan untuk mengetahui pengaruh komunikasi dakwah MUI terhadap kepatuhan umat Islam di Cinere, Depok, Jawa Barat dalam melaksanakan fatwa-fatwa MUI terkait dengan wabah covid-19. Berdasarkan hasil penelitian yang dilakukan, maka dapat diambil kesimpulan bahwa terdapat pengaruh yang kuat antara komunikasi dakwah MUI terhadap kepatuhan umat Islam di Cinere Depok, Jawa Barat, dalam melaksanakan fatwa-fatwa MUI. MUI sebagai komunikator yang memberikan pesan kepada umat Islam. Respon umat Islam yang positif terhadap komunikasi dakwah MUI menunjukkan bahwa stimulus yang diberikan diterima oleh komunikan.
\end{abstract}

Kata kunci : fatwa;MUl;covid-19;kepatuhan; umat.

\section{PENDAHULUAN}

Allah SWT telah menurunkan Al-Qur'an kepada Nabi Muhammad SAW secara sempurna dan lengkap. Hal ini tidak boleh dipahami bahwa semua aspek dalam kehidupan manusia diatur secara rinci oleh Al-Quran maupun Al-Hadits. Selain karena ada perbedaan keadaan pada saat turunnya Al Quran dengan kehidupan manusia pada setiap zamannya, juga lahirnya masalahmasalah baru akan terus berkembang dan diperlukan aturan-aturan turunan dalam melaksanakan ajaran Islam dalam kehidupan beragama sehari-hari.

Sesuai dengan pedoman beragama tentang sistematika pengambilan hukum dalam Islam bahwa sumber dan dasar hukum yang utama dan pertama adalah Al-Qur'an, Al-Hadits/Al-Sunnah dan Ijma ulama (ijtihad). Jika terjadi persoalan baru bagi kalangan umat Islam di suatu tempat tertentu atau di suatu masa waktu tertentu maka persoalan tersebut dikaji apakah perkara yang dipersoalkan itu sudah ada dan jelas ketentuannya dalam Al Quran atau Al Hadist. Sekiranya sudah ada maka persoalan tersebut harus mengikuti ketentuan yang ada sebagaimana disebutkan dalam Al Quran atau Al Hadits itu. Namun jika persoalan tersebut merupakan perkara yang tidak jelas atau tidak ada ketentuannya dalam Al-Quran dan Al-Hadits, pada saat itulah maka umat Islam memerlukan ketetapan Ijtihad (Amir, 1997)

Aktifitas ijtihad menjadi bahan penting bagi kebutuhan umat Islam seiring dengan berbagai perkembangan yang terjadi di belahan dunia saat ini. Oleh karenanya, banyak usaha-usaha yang kemudian digagas demi menstabilkan gerak aplikatif masyarakat Islam demi satu arah kemajuan. Kebutuhan akan Ijtihad ini terus berkembang. Hal ini dikarenakan:

a. Setelah Rasul wafat, beliau meninggalkan AlQur'an dan Sunnah. Nash Al-Qur'an dan Sunnah tersebut jelas tidak akan bertambah, sementara persoalan dan masalah yang dihadapi kaum muslimin dari zaman ke zaman terus berkembang, karena itu kebutuhan akan ijtihad menjadi sebuah yang niscaya.

b. Ketika wilayah kekuasaan Islam semakin luas, ke Persia, Syam, Mesir, Afrika Utara bahkan sampai ke spanyol, Turki dan India, permasalahan yang dihadapi ulama semakin kompeks, maka ijtihad semakin berperan dalam mengistinbat hukum. (Ahmad, 2013)

Ijtihad merupakan faktor penting bagi pembinan dan perkembangan hukum Islam. Ijtihad dilakukan untuk menjawab permasalahan yang timbul di masyarakat yang belum diketahui. Sedemikian pentingnya ijtihad dalam tatanan hukum Islam 
sehingga banyak di negara yang berpenduduk muslim mempunyai lembaga ijtihad/fatwa, seperti Dar-Iftah di Mesir, Lajnah Daimah Lil Ifta di Saudi Arabi, Majlis Kebangsaan Bagi Hal Ehwal Agama Islam Malaysa (MKI) di Malaysia, Majlis Ugama Islam Singapura (MUIS) di Singapura, dan Majelis Ulama Indonesia (MUI) di Indonesia (Isa, 2017)

Majelis Ulama Indonesia atau yang biasa disingkat dengan MUI didirikan pada tanggal 17 Rajab $1375 \mathrm{H}$ bertepatan dengan tanggal 26 Juli 1975 M. Lembaga tersebut didirikan sebagai wadah musyawarah para ulama, zu'ama dan cendekiawan muslim dalam mengayomi umat dan mengembangkan kehidupan yang Islami. Tujuan didirikannya MUI adalah untuk terwujudnya masyarakat yang berkualitas (khaira ummah), dan negara yang aman, damai adil dan makmur rohaniah dan jasmaniah yang diridhoi oleh Allah SWT (baldatun thayyibatun wa rabbun ghofur). Sedangkan fungsi dari Majelis Ulama Indonesia (MUI) adalah :

1. Sebagai wadah musyawarah para ulama, zueama dan cendikiawan muslim dalam mengayomi umat dan mengembangkan kehidupan yang islami, demokratis, akomodatif, dan aspiratif.

2. Sebagai wadah silaturahim para ulama, zu'eama dan cendikiawan muslim untuk mengembangkan dan mengamalkan ajaran Islam dan menggalang ukhwah islamiyah.

3. Sebagai wadah yang mewakili umat Islam dan hubungan serta konsultasi antar umat beragama.

4. Sebagai pemberi fatwa kepada umat Islam dan pemerintah, baik diminta maupun tidak diminta. (mui.go.id)

Berdasarkan fungsi-fungsi tersebut di atas, yang paling menojol dan berpengaruh terhadap kehidupan berbangsa dan bernegara, khususnya bagi umat Islam adalah fungsi MUI sebagai pemberi fatwa (mufti). Fatwa biasanya muncul sebagai respon pertanyaan yang bersumber dari masyarakat maupun kebijakan pemerintah. Fatwa dapat dijadikan dasar dalam tindakan bagi umat Islam di Indonesia maupun bagi pemerintah. MUI telah menerbitkan berbagai macam fatwa dalam masalah ibadah, hukum, sosial, politik, politik,etika, ekomonomi dan bahkan juga kesehatan.

Terkait dengan wabah covid-19 di Indonesia, sejak kasus pertama diumumkan oleh Presiden Joko Widodo, yaitu pada Senin, 2 Maret 2020 dengan 2 orang positif terjangkit Covid-19 hingga kini semakin melonjak tajam. Pada kamis (18/7/2020) jumlah pasien yang terinfeksi virus corona bertambah menjadi 84.882 orang, 43.268 orang dinyatakan sembuh, dan 4.016 orang meninggal (covid19.go.id)

Sebagai lembaga tertinggi yang menaungi ulama dan cendikiawan muslim di Indonesia, MUI merespon dengan cepat fenomena wabah virus corona ini dengan mengeluarkan fatwa. Terdapat tujuh fatwa yang telah dikeluarkan oleh MUI, antara lain :

1. Fatwa MUI nomor 14 tahun 2020 tentang penyelanggaran ibadah dalam situasi terjadi wabah covid-19, tanggal 17 Maret 2020

2. Fatwa MUI nomor 17 tentang pedoman kaifiat sholat bagi tenaga kesehatan yang memakai Alat Pelindung Diri (APD) saat merawat dan menangani pasien covid-19, tanggal 28 Maret 2020

3. Fatwa MUI nomor 18 tentang pengurusan jenazah muslim terinfeksi covid-19, tanggal 28 Maret 2020

4. Fatwa MUI nomor 23 tahun 2020 tentang pemanfaatan harta zakat, infaq, dan shadaqah untuk penanggulangan wabah covid-19 dan dampaknya, tanggal 11 Mei 2020

5. Fatwa MUI nomor 28 tahun 2020 tentang panduan kaifiat takbir dan sholat idul fitri saat covid-19, tanggal 14 Mei 2020

6. Fatwa MUI nomor 31 athun 2020 tentang penyelenggaran sholat Jum'at dan jamaah untuk mencegah penularan covid-19, tanggal 4 Juni 2020

7. Fatwa MUI nomor 36 tahun 2020 tentang sholat idhul adha dan penyembelihan hewan kurban saat wabah covid-19, tanggal 10 Juli 2020 (mui.or.id/fatwa).

Untuk mensosialisasikan fatwa-fatwa ini, selain menggunakan website resmi dan TV non komersial, MUI juga memakai media massa seperti televisi, radio, media cetak dan media online. Secara struktural, MUI menyebarkan fatwa-fatwa ini melalui cabang MUI pada tingkat provinsi, kota madya/kabupaten dan kecamatan serta melalui sarana masjid dan majelis taklim.

Fatwa MUI yang melarang ibadah berjamaah di tengah pandemi virus corona sejalan dengan pandangan NU, Muhammadiyah, dan Kementerian Agama. Cendekiawan muslim Quraish Shihab menganggap anjuran berada dan beraktivitas di rumah selama masa pandemi corona ini wajib untuk ditaati. Bahkan bagi pelanggarnya dapat dikatakan berdosa.

Ketua Dewan Pertimbangan Majelis Ulama Indosia (MUI) Din Syamsuddin meminta masyarakat Indonesia khususnya umat Islam agar senantiasa mematuhi anjuran para ahli kesehatan dan fatwa dari MUI. Dalam agama Islam, fatwa dijadikan sebagai landasan bertindak dan pandangan terhadap suatu masalah yang berkaitan dengan hukum Islam. Fatwa tersebut nantinya harus ditaati dan dijalankan oleh semua umat Islam

Tuntunan untuk mentaati para alim ulama (MUI) tertuang dalam Al-Qur'an, surah An-Nisaa' ayat 59. Allah SWT memerintahkan agar menaati Allah dan Rasul-nya serta ulil amri. Pengertian ulil 
amri pada ayat itu, dalam pandangan banyak ulama terdahulu (salaf) adalah para ulama.

Walaupun sudah ada fatwa MUI untuk tidak melaksanakan ibadah berjamaah sehubungan dengan penyebaran covid-19, namun belum sepenuhnya ditaati oleh masyarakat. misalnya, beberapa masjid di Jakarta, Bogor, Depok, Tangerang, Bekasi dan daerah yang lainnya masih tetap melaksanakan kegiatan ibadah seperti, shalat 5 waktu, shalat Jum'at, shalat tarawih, dan shalat idul fitri, sehingga tidak mengherankan jika jumlah yang terpapar covid di Indonesia terus meningkat.

Berdasarkan uraian di atas, maka penelitian pengaruh komunikasi dakwah Majelis Ulama Indonesia terhadap kepatuhan umat Islam di Cinere Depok dalam melaksanakan fatwa-fatwa MUI yang berkaitan dengan wabah covid-19 menjadi menarik untuk dilakukan.

\section{Tujuan Penelitian}

1. Untuk mengetahui apakah ada pengaruh antara komunikasi dakwah Majelis Ulama Indonesia terhadap kepatuhan umat Islam di Cinere Depok dalam melaksanakan fatwafatwa MUI yang berkaitan dengan wabah covid-19

2. Untuk mengetahui berapa besar komunikasi dakwah Majelis Ulama Indonesia terhadap kepatuhan umat Islam di Cinere Depok dalam melaksanakan fatwa-fatwa MUI yang berkaitan dengan wabah covid-19.

\section{Urgensi Penelitian}

Penelitian tentang Majelis Ulama Indonesia (MUI) sudah banyak dilakukan, namun penelitian tentang pengaruh dakwah MUI dilihat dari sudut pandang komunikasi, mungkin jarang dilakukan. Hal ini disebabkan karena komunikasi dakwah MUI akan terus berkembangan sesuai dengan perkembangan zaman, termasuk dengan mengunakan media komunikasi dakwah terkini. Selain itu, adanya perubahan dalam aspek sosial dan politik serta kecenderungan masyarakat yang berubah karena dampak dari globalisasi yang semakin sulit dihindari, dikhawatirkan akan membuat nilai-nilai ajaran agama, salah satu di antaranya adalah kepatuhan pada ulama akan mulai terkikis di masyarakat. Oleh karena itu, pentingnya dilakukan penelitian ini adalah untuk mengetahui pengaruh komunikasi dakwah MUI terhadap kepatuhan umat Islam di Cinere Depok pada fatwa MUI agar dapat dihasilkan rekomendasi untuk menerapkan komunikasi dakwah yang tepat dan bijaksana sehingga muncul kembali kepatuhan umat Islam pada ulama.

\section{TINJAUAN PUSTAKA}

Teori S-O-R (Stimulus-Organism-Response)
Teori SOR merupakan proses komunikasi yang menimbulkan reaksi khusus, sehingga seseorang dapat mengharapkan dan memperkirakan kesesuaian antara pesan dan reaksi komunikan. Unsur-unsur pada model ini adalah pesan (Stimulus), komunikan (Organism), dan efek (Response).

Unsur-unsur dalam model ini adalah:

1. Pesan (Stimulus), merupakan pesan yang disampaikan komunikator kepada komunikan. Pesan yang disampaikan tersebut dapat berupa tanda dan lambang.

2. Komunikan (Organism), merupakan keadaan komunikan disaat menerima pesan. Pesan yang disampaikan oleh komunikator diterima sebagai informasi, dan komunikan akan memperhatikan informasi yang disampaikan oleh komunikator. Perhatian disini diartikan bahwa komunikan akan memperhatikan setiap pesan yang disampaikan melalui tanda dan lambang. Selanjutnya, komunikan mencoba untuk mengartikan dan memahami setiap pesan yang disampaikan oleh komunikator.

3. Efek (Respons), merupakan dampak dari efek komunikasi. Efek dari komunikasi adalah perubahan sikap afektif, kognitif, konatif. Efek kognitif merupakan efek yang ditimbulkan setelah adanya komunikasi, efek kognitif berarti bahwa setiap informasi menjadi bahan pengetahuan bagi komunikan (Effendy, 2017).

Dalam penelitian ini, komunikasi dakwah MUI merupakan pesan/ stimulus. Sedangkan masyarakat sebagai komunikan. Efek yang dihasilkan adalah perubahan sikap umat Islam.

\section{Dakwah \\ Pengertian dakwah}

Dalam kamus bahasa Arab al-Munawwir, dakwah berarti berarti doa, seruan, panggilan, ajakan, undangan maupun permintaan (Munawwir,1997). Sedangkan dalam Kamus Besar Bahasa Indonesia (KBBI daring), dakwah didefinisikan dengan penyiaran atau propaganda, penyiaran agama dan pengembangannya di kalangan masyarakat, seruan untuk memeluk, mempelajari dan mengamalkan ajaran agama.

Menurut Prof. Dr. M. Quraish Shihab (1998), dakwah didefinisikan sebagai seruan atau ajakan kepada keinsafan, atau usaha mengubah situasi kepada situasi yang lebih baik (dari yang awalnya berperilaku buruk sampai kepada arah yang lebih baik). Baik kepada pribadi maupun kepada masyarakat, dan dakwah seharusnya berperan dalam pelaksanaan ajaran Islam secara lebih menyeluruh dalam berbagai aspek kehidupan.

Pengertian Komunikasi dakwah 
Komunikasi dakwah adalah komunikasi yang unsur-unsurnya disesuaikan visi dan misi dakwah. Menurut Toto Tasmara (1997), bahwa komunikasi dakwah adalah suatu bentuk komunikasi yang khas dimana seseorang komunikator menyampaikan pesan-pesan yang bersumber atau sesuai dengan ajaran al Qur'an dan Sunnah, dengan tujuan agar orang lain dapat berbuat amal shaleh sesuai dengan pesan-pesan yang disampaikan. Jadi dari segi proses komunikasi dakwah hampir sama dengan komunikasi pada umumnya, tetapi yang membedakan hanya pada cara dan tujuan yang akan dicapai.

\section{Unsur-Unsur Dakwah}

Menurut Mohammad Hasan yang dimaksud dengan unsur-unsur dakwah adalah komponenkomponen dakwah yang selalu ada dalam setiap kegiatan dakwah, yaitu :

1. Dai (Subyek) Dakwah

Yang dimaksud dengan dai adalah orang yang menyampaikan dakwah secara lisan maupun tulisan yang berupa nasehat atau perbuatan baik secara individu, kelompok, lembaga, maupun organisasi. Da'i merupakan sebutan unsur dakwah yang paling penting, sebab tanpa da'i, Islam hanya merupakan ideologi yang tidak terwujud dalam kehidupan masyarakat.

Hamzah Ya'kub dalam Mohammad Hasan mengatakan bahwa da'i harus memiliki sifat-sifat sebagai berikut :

a. Memiliki kemampuan yang cukup tentang AlQur'an dan Sunnah Rasul dan ilmu-ilmu lain yang berinduk kepada kedua, seperti ilmu tafsir, ilmu hadits, sejarah kebudayaan Islam dan sebagainya.

b. Memiliki pengetahuan yang menjadi alat kelengkapan dakwah seperti ilmu dakwah, psikologi, anthropologi dan sebagainya

c. Penyantun dan lapang dada, karena apabila dia keras dan sempit pandang, maka larilah manusia meninggalkannya.

d. Berani kepada siapapun dalam menyatakan membela dan mempertahankan kebenaran.

2. Mad'u (Obyek atau Penerima) Dakwah

Yaitu manusia yang menjadi sasaran dakwah atau manusia penerima dakwah, baik secara individu atau kelompok, baik beragama Islam ataupun non Islam, dengan kata lain manusia secara keseluruhan.

\section{Maddah (Materi) Dakwah}

Maddah adalah mengenai isi pesan atau materi yang akan dsampaikan da'i kepada mad'u, yang menjadi maddah dakwah adalah ajaran Islam itu sendiri. Menurut Mahmud Syaltout dalam Abuddin Nata (1993), Islam meliputi tiga bidang, sebagai berikut :

\section{A. Bidang akidah}

Pengertian akidah dari segi istilah sering disamakan dengan pengertian keimanan. Keimanan atau akidah itu terdiri dari enam perkara :

a. Iman kepada Allah SWT

b. Iman kepada malaikat

c. Iman kitab-kitab suci yang Allah SWT yang diturunkan kepada para Rasul

d. Iman kepada para Nabi dan rasul Allah SWT

e. Iman kepada hari akhir

f. Iman kepada takdir

B. Bidang ibadah/syariah Menurut Musthafa Zarqa dalam Dede Rosyada (1993) membagi ibadah/syariah itu menjadi enam bidang :

a. Bidang ubudiyah yaitu ketentuan hukum yang berkaitan dengan peribadatan, seperti sholat, puasa, zakat, haji dll

b. Bidang ahwal al-syakhsyiah yaitu ketentuan hukum yang berkaitan dengan kehidupan keluarga, seperti perkawinan, perceraian, nafkah, ketentuan nasab dll

c. Bidang muamalah yaitu ketentuan hukum yang berkaitan dengan hubungan sosial dalam konteks hubungan ekonomi dan jasa, seperti jual beli, sewa menyewa, gadai, dll

d. Bidang jinayah yaitu ketentuan hukum yang berkaitan dengan sanksi terhadap pelaku tindak kejahatan kriminal, seperti qishash, diyat, hudud dll

e. Bidang siyasah yaitu ketentuan hukum yang mengatur masalah hubungan warga negara dan pemerintah atau sebaliknya, mengatur hubungan satu negara dengan negara lainnya.

f. Bidang khuluqiyah yaitu ketentuan yang mengatur etika pergaulan antara sesame muslim serta muslim dengan non muslim dalam tatanan kehidupan sosial.

C. Bidang akhlak

Akhlak merupakan koleksi kaidah/norma yang mengatur hubungan, baik antara makhluq (ciptaan) dengan khaliq (pencipta) maupun antara sesama makhluq.

4. Wasilah (Media) Dakwah

Wasilah yaitu alat atau media yang digunakan untuk menyampaikan materi dakwah (ajaran Islam) kepada mad'u. Wasilah dibagi menjadi lima yaitu: lisan, tulisan, lukisan, audio visual dan akhlak. penjelasan dari kelima wasilah tersebut adalah sebagai berikut:

a. Lisan, merupakan wasilah dakwah yang paling sederhana serta paling umum digunakan yang menggunakan lidah dan suara, dakwah dengan wasilah ini dapat berbentuk pidato, ceramah, kuliah, bimbingan, penyuluhan. 
b. Tulisan, wasilah dakwah dengan tulisan dapat berbentuk buku, majalah, surat kabar, surat menyurat, spanduk.

c. Lukisan, wasilah dakwah dengan lukisan antara lain dengan gambar dan karikatur.

d. Audio visual, yaitu wasilah dakwah yang merangsang indra pendengaran atau penglihatan dan kedua-duanya, seperti televisi, film, internet.

e. Akhlak, yaitu perbuatan nyata yang mencerminkan ajaran Islam dapat dinikmati serta didengarkan oleh mad'u.

5. Thariqah (Metode) Dakwah

Thariqah adalah metode atau cara-cara yang digunakan dalam berdakwah. Ada tiga metode pokok dalam berdakwah

a. Hikmah, yaitu berdakwah dengan memperhatikan situasi dan kondisi sasaran dakwah denga menitik beratkan pada kemampuan mereka, sehingga dalam menjalankan ajaran-ajaran Islam selanjutnya, mereka tidak merasa terpaksa atau keberatan.

b. Mauidhah Hasanah, yaitu berdakwah dengan memberikan nasihat-nasihat atau menyampaikan ajaran-ajaran Islam dengan kasih sayang.

c. Mujadalah, yaitu berdakwah dengan cara bertukar pikiran dan membantah dengan cara yang sebaik-baiknya dengan tidak memberikan tekanan-tekanan.

6. Atsar (Efek) Dakwah

Atsar sering disebut juga dengan feedback (umpan balik) dari proses dakwah. Kegiatan dakwah harus diarahkan untuk memenuhi tiga aspek perubahan dari obyeknya, yakni perubahan pada aspek pengetahuannya (knowledge), aspek sikapnya (attitude), aspek perilaku (behavioral). Berkenaan dengan ketiga hal tersebut, Jalaluddin Rahmat dalam Mohammad Hasan, menyatakan:

a. Efek kognitif terjadi bila ada perubahan pada apa yang diketahui, dipahami, atau perspektif khalayak. Efek ini berkaitan dengan transmisi pengetahuan, keterampilan, kepercayaan, atau informasi.

b. Efek afektif timbul bila ada perubahan pada apa yang dirasakan disenangi atau dibenci khalayak, yang meliputi segala yang berhubungan dengan, emosi, sikap serta nilai.

c. Efek behavioral merujuk pada perilaku nyata yang dapat diamati, yang meliputi pola-pola tindakan, kegiatan atau kebiasaan berperilaku.

\section{Kepatuhan}

\section{Definisi kepatuhan}

Dalam kamus besar Bahasa Indonesia, patuh adalah suka menurut perintah, taat pada perintah. Sedangkan kepatuhan adalah perilaku sesuai aturan dan berdisiplin (Pranoto, 2007). Sedangkan menurut Feldman dalam Septi Kusumadewi (2012) mendifinisikan kepatuhan merupakan suatu perubahan sikap dan tingkah laku seseorang dalam mengikuti permintaan atau perintah orang lain.

\section{Aspek-aspek Kepatuhan}

Menurut Darley dan Blass (Dalam Hartono, 2006) kepatuhan terdiri atas aspek-aspek sebagai berikut :

a. Mempercayai (belief)

lebih patuh apabila mereka percaya bahwa tujuan dari dibentuknya suatu peraturan itu merupakan sesuatu yang penting. Individu percaya bahwa mereka diperlakukan secara adil oleh orang yang memberi perintah atau biasa disebut pemimpin, percaya pada motif pemimpin dan menggangap bahwa individu tersebut bagian dari organisasi atau kelompok yang ada dan memiliki aturan yang harus diikuti.

b. Menerima (accept)

Individu yang patuh menerima dengan sepenuh hati perintah dan permintaan yang ada dalam peraturan yang telah dipercayainya. Mempercayai dan menerima merupakan aspek yang berkaitan dengan sikap individu.

c. Melakukan (act)

Melakukan dan memilih taat terhadap peraturan dengan sepenuh hati dan dalam keadaan sadar. Melakukan sesuatu yang diperintahkan atau menjalankan suatu aturan dengan baik, maka idividu tersebut bisa dikatakan telah memenuhi aspek-aspek dari kepatuhan

\section{METODOLOGI PENELITIAN Metode Penelitian}

Penelitian ini menggunakan metode kuantitatif dengan pendekatan regresional. Penelitian ini akan mengkaji hubungan kausal (hubungan yang bersifat sebab-akibat)

\section{Lokasi dan Waktu Penelitian}

Lokasi penelitian adalah di Kecamatan Cinere kota madya Depok Jawa Barat. Penelitian akan dimulai pada Juli-Agustus 2020

\section{Populasi dan Teknik Pengambilan Sampel}

Jumlah populasi di dalam penelitian ini besar, sehingga rumus Slovin digunakan untuk mengukur sampel: (Kriyantono, 2006)

Dimana:

$$
\frac{n=\quad N}{1+(\mathrm{e}) 2}
$$

$\mathrm{n}=$ ukuran sampel

$\mathrm{N}=$ ukuran populasi

$\mathrm{e}=$ batas ketelitian yang diinginkan

\section{Teknik Analisis Data}

Dalam penelitian ini digunakan analisis regresi linier sederhana karena data-data yang ada di dalam penelitian ini masih bersifat sederhana yaitu hanya satu variabel bebas dan satu variabel terikat. Analisis regresi ini digunakan jika korelasi antara 
dua variabel mempunyai hubungan kausal (sebabakibat) dan hubungan fungsional. (Kriyantono, 2006)

Uji statistik analisis regresi digunakan untuk mengetahui ada atau tidaknya peran antara variable $\mathrm{X}$ terhadap variabel $\mathrm{Y}$ dengan menggunakan rumus sebagai berikut $: Y=a+b X$

$\mathrm{Y}=$ Variabel Terikat

$\mathrm{X}=$ Variabel Bebas

$\mathrm{a}=$ Nilai intercept (konstan) atau harga $\mathrm{Y}$ bila $\mathrm{X}=$ 0

$\mathrm{b}=$ Koefisien regresi, yaitu angka peningkatan atau penurunan variabel

\section{Operasionalisasi variabel}

Variabel X

\begin{tabular}{|c|c|c|}
\hline Variabel & Dimensi & Indikator \\
\hline \multirow[t]{4}{*}{$\begin{array}{l}\text { Unsur-Unsur } \\
\text { Komunikasi } \\
\text { dakwah MUI }\end{array}$} & Subjek & 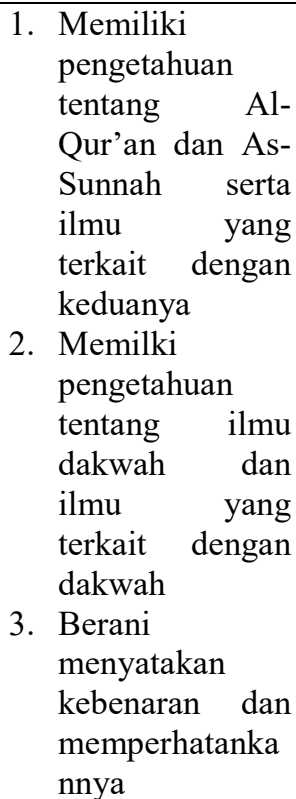 \\
\hline & Materi & $\begin{array}{l}\text { 1. Fatwa MUI No. } \\
14 \text { tahun } 2020 \\
\text { 2. Fatwa MUI No, } \\
28 \text { tahun } 2020 \\
\text { 3. Fatwa MUI No. } \\
31 \text { tahun } 2020 \\
\text { 4. Fatwa MUI No. } \\
36 \text { tahun } 2020\end{array}$ \\
\hline & Media & $\begin{array}{l}\text { 1. Lisan } \\
\text { 2. Tulisan } \\
\text { 3. Audio visual } \\
\text { 4. Akhlak }\end{array}$ \\
\hline & Metode & $\begin{array}{l}\text { 1. Hikmah } \\
\text { 2. Nasihat/pengaja } \\
\text { ran yang baik } \\
\text { 3. } \\
\text { Berdiskusi/tukar } \\
\text { pikiran }\end{array}$ \\
\hline \multicolumn{3}{|l|}{ Variabel Y } \\
\hline VARIABEL & imensi & Indikator \\
\hline
\end{tabular}

\begin{tabular}{|c|c|c|}
\hline \multirow{3}{*}{$\begin{array}{l}\text { Kepatuhan } \\
\text { umat Islam } \\
\text { dalam } \\
\text { menjalank } \\
\text { an fatwa } \\
\text { MUI }\end{array}$} & $\begin{array}{l}\text { Memperca } \\
\text { yai }\end{array}$ & $\begin{array}{l}\text { 1. Percaya pada tujuan fatwa } \\
\text { 2. Percaya pada ulama } \\
\text { 3. Percaya pada motif }\end{array}$ \\
\hline & Menerima & $\begin{array}{l}\text { 1. Menerima yang tertulis } \\
\text { 2. Menerima yang tidak tertulis }\end{array}$ \\
\hline & Melakukan & $\begin{array}{l}\text { 1.Dalam keadaan sadar } \\
\text { 2.Dengan sepenuh hati }\end{array}$ \\
\hline
\end{tabular}

\section{HASIL PENELITIAN DAN PEMBAHASAN}

\section{Hasil Penelitian}

Analisis statistik pernyataan-pernyataan pada variabel $\mathrm{X}$

\begin{tabular}{|c|c|c|c|c|c|c|}
\hline \multicolumn{7}{|c|}{ Descriptive Statistics } \\
\hline & H & Aarge: & Whimun & Hamum & Narn & Sst Deation \\
\hline tem! & 41 & 4 & 1 & 5 & 436 & .911 \\
\hline tent: & 41 & 4 & 1 & 0 & 4,24 & 830 \\
\hline tema: & 41 & 7 & 2 & a & 4,41 & 741 \\
\hline teemt & 41. & 2 & 3. & 9 & 4.48 & 297 \\
\hline teme: & 41 & 7 & 2 & 0 & 4,76 & (69? \\
\hline teme & 41 & 4 & 1 & 9 & 454 & .981 \\
\hline terul & 41 & 3 & 2 & 9 & 4,88 & (6) \\
\hline tent: & 41 & 4 & 1 & 8 & 4,77 & 1,043 \\
\hline teme & 41 & 3 & 2 & 5 & 4,58 & .610 \\
\hline temlo & 41 & 4 & 1 & 0 & 4.,41 & $\operatorname{Bas}$ \\
\hline temil & 41 & 4 & 1 & A & 4.38 & 1,022 \\
\hline $\operatorname{temi12}$ & 41 & 4 & 1 & 9 & 438 & .072 \\
\hline temin & 41 & 4 & 1 & 0 & 4,41 & .921 \\
\hline temil4. & 41 & 1 & 2 & 5 & 4.34 & $\pi 8$ \\
\hline temis & 41 & 3 & 2 & 9 & 434 & .702 \\
\hline teminto & 41 & 4 & 1 & 8 & 4.24 & 898 \\
\hline temil? & 41 & 3 & 2 & 5 & 4.51 & $\pi 11$ \\
\hline $\tan 29$ & 41 & 3 & 2 & 0 & 1,41 & .670 \\
\hline temis & 41 & 7 & 2 & A & 4,54 & $\pi 11$ \\
\hline $\operatorname{ten} 30$ & 41. & 4 & 1 & 9 & 4,17 & 803 \\
\hline volifhilintusai & 41 & & & & & \\
\hline
\end{tabular}

Nilai Rata-Rata Keseluruhan Pada Variabel X

\begin{tabular}{cc}
\hline Dimensi & $\begin{array}{c}\text { Rata- } \\
\text { Rata }\end{array}$ \\
\hline Subyek dakwah & 4,33 \\
\hline Materi Dakwah & 4,51 \\
\hline Media Dakwah & 4,36 \\
\hline Metode Al-Qur'an & 4,37 \\
\hline $\begin{array}{c}\text { Hasil rata-rata } \\
\text { keseluruhan }\end{array}$ & $\mathbf{4 , 3 9}$ \\
\hline
\end{tabular}

Rentang Skala

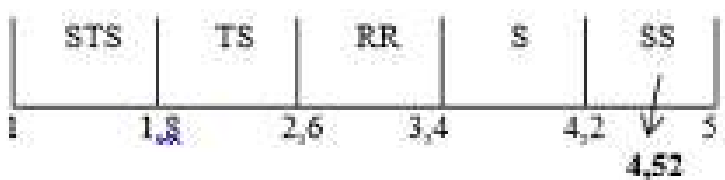

Berdasarkan tabel di atas, didapatkan rata-rata secara keseluruhan sebesar 4,52 yang memasuki rentang skala sangat setuju. Dengan ini maka dapat 
disimpulkan bahwa umat Islam Cinere Depok menyatakan sangat setuju (kepatuhan) dalam melaksanakan fatwa-fatwa MUI yang berkaitan dengan wabah covid-19.

Uji Korelasi

\section{Correlations}

\begin{tabular}{|c|c|c|c|}
\hline & & $\begin{array}{l}\text { Kepatuhan } \\
\text { Umatislam }\end{array}$ & $\begin{array}{c}\text { Komunikasi } \\
\text { Dakwah Majelis } \\
\text { Ulama Indonesia }\end{array}$ \\
\hline \multirow[t]{3}{*}{ Kepatuhan UmatIslam } & Pearson Correlation & 1 & $842^{\prime \prime}$ \\
\hline & Sig. (2-tailed) & &, 000 \\
\hline & N & 41 & 41 \\
\hline \multirow{3}{*}{$\begin{array}{l}\text { Komunikasi Dałwah } \\
\text { Majellis Ulama Indonesia }\end{array}$} & Pearson Correlation & $.842^{\prime \prime \prime}$ & 1 \\
\hline & Sig. (2-tailed) &, 000 & \\
\hline & $N$ & 41 & 41 \\
\hline
\end{tabular}

**. Correlation is significant at the 0.01 level (2-tailed).

Nilai 0,842 merupakan nilai $r$ hitung. Angka ini menunjukkan korelasi atau hubungan yang kuat antara komunikasi dakwah Majelis Ulama Indonesia dan kepatuhan umat Islam di Depok, artinya jika komunikasi dakwah Majelis Ulama Indonesia meningkat, maka kepatuhanumat Islam di Depok tentu bertambah.

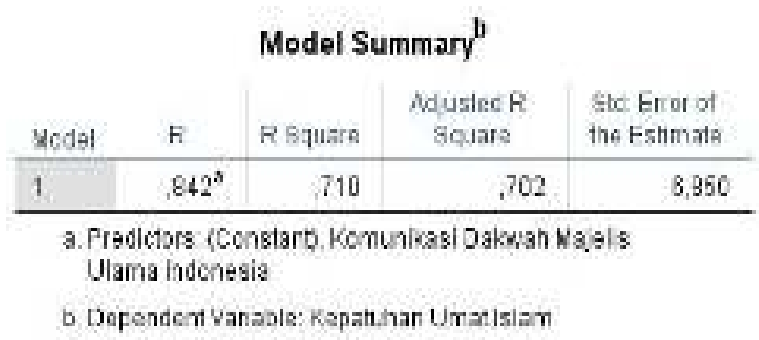

$\mathrm{R}$ disebut juga dengan koefisien korelasi. Dapat dibaca bahwa nilai koefisien korelasi antara variabel Komunikasi Dakwah Majelis Ulama Indonesia (X) terhadap Kepatuhan Umat Islam (Y) adalah 0,842 .

$\mathrm{R}$ Square disebut koefisien determinasi. Dari tabel dapat dibaca bahwa nilai $R$ square $\left(\mathrm{R}^{2}\right)$ adalah 0,710 , artinya $71,00 \%$ variasi yang terjadi terhadap tingggi atau rendahnya Kepatuhan Umat Islam disebabkan variasi Komunikasi Dakwah Majelis Ulama Indonesia sedangkan sisanya $(29,00$ \%) tidak dapat diterangkan.

\begin{tabular}{|c|c|c|c|c|c|c|}
\hline \multicolumn{7}{|c|}{ ANOVA $^{\mathrm{A}}$} \\
\hline \multicolumn{2}{|l|}{ Hodel } & $\begin{array}{l}\text { Sund } \\
\text { Squares }\end{array}$ & df & Mean Square & i & Sig. \\
\hline \multirow[t]{3}{*}{1} & 89988в5100 & 1474,008 & 1 & 1.174, 008 & 95358 & $.000^{6}$ \\
\hline & Ros dual & 1829,797 & 39. & 46998 & & \\
\hline & Total & 6303,805 & 10 & & & \\
\hline
\end{tabular}

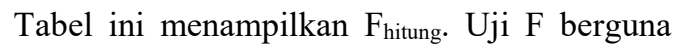
untuk menentukan apakah model penaksiran yang digunakan tepat atau tidak.

Model persamaan yang digunakan adalah model linear $\hat{\mathbf{Y}}=\mathbf{a}+\mathbf{b X}$

Untuk menguji apakah model linear $\hat{\mathbf{Y}}=\mathbf{a}+$ bX tersebut sudah tepat atau belum, $F_{\text {hitung }}$ pada tabel anova perlu dibandingkan dengan $\mathrm{F}_{\text {tabel }}$

$\mathrm{F}_{\text {hitung }}=95,358$

$\mathrm{F}_{\text {tabel }}$ dilihat pada:

- taraf signifikansi 5\%

- df pembilang = jumlah variabel $-1=(2-1)=1$

- df penyebut $=$ jumlah data - jumlah variabel $=$ $(41-2)=39$

$\mathrm{F}_{\text {tabel }}=4,09$.

Oleh karena $F_{\text {hitung }}>F_{\text {tabel }}$ maka dapat disimpulkan bahwa model linear

$\hat{\mathbf{Y}}=\mathbf{a}+\mathbf{b X}$ sudah tepat dan dapat digunakan.

Selain membandingkan $F_{\text {hitung }}$ dengan $F_{\text {tabel, }}$ ada cara yang lebih mudah untuk menentukan ketepatan model di atas, yaitu dengan membandingkan probabilitas (pada tabel Anova tertulis Sig) dengan taraf nyatanya $(0,05$ atau 0,01$)$.

- Jika probabilitasnya $>0,05$ maka model ditolak

- Jika probabilitasnya $<0,05$ maka model diterima

Dapat dilihat probabilitas (Sig) adalah $0,000<$ 0,05 berarti model diterima atau dapat disimpulkan bahwa bentuk persamaan linear $\hat{\mathbf{Y}}=\mathbf{a}+\mathbf{b X}$ sudah tepat. 


\begin{tabular}{|c|c|c|c|c|c|c|}
\hline & & & ficients ${ }^{a}$ & & & \\
\hline & & $\begin{array}{r}\text { Unsta } \\
\text { Coe }\end{array}$ & dardized & $\begin{array}{l}\text { Standardized } \\
\text { Coefficients }\end{array}$ & & \\
\hline Model & & $B$ & Stol. Error & Beta & $t$ & Sig. \\
\hline 1 & (Constant) & 28,609 & 7,777 & & 3,679 &, 001 \\
\hline & $\begin{array}{l}\text { Komunikasi Dakwah } \\
\text { Najelis Ulama Indonesia }\end{array}$ & .848 & .087 & .842 & 9,765 &, 000 \\
\hline
\end{tabular}

a. DependentVariable: Kepatuhan Umatlslam

\section{Tabel Coefficients}

- Kolom Standardized Coefficients Beta

$>$ Constant (Konstanta) $=28,609$

$>$ Komunikasi Dakwah MUI $=0,848$

Dari sini didapat persamaan regresi

$$
\hat{\mathbf{Y}}=\mathbf{2 8 , 6 0 9}+\mathbf{0 , 8 4 8 X}
$$

\section{a Kolom t}

Uji $t$ berguna untuk menguji signifikansi koefisien regresi (b), yaitu apakah variabel independen $(\mathrm{X})$ berpengaruh secara nyata atau tidak.

Hipotesis:

Ho $=$ Komunikasi Dakwah Majelis Ulama Indonesia tidak berpengaruh nyata terhadap Kepatuhan Umat Islam

$\mathrm{Ha}=$ Komunikasi Dakwah Majelis Ulama Indonesia berpengaruh nyata terhadap Kepatuhan Umat Islam

Pengambilan Keputusan

- Jika $-\mathrm{t}_{\text {tabel }}<\mathrm{t}_{\text {hitung }}<\mathrm{t}_{\text {tabel }}$ maka Ho diterima

- Jika $\mathrm{t}_{\text {hitung }}<-\mathrm{t}_{\text {hitung }}<\mathrm{t}_{\text {tabel }}$ atau $\mathrm{t}_{\text {hitung }}>\mathrm{t}_{\text {tabel }}$ maka Ho ditolak

- $\mathrm{t}_{\text {tabel }}$ dilihat dengan derajat bebas $=\mathrm{n}-\mathrm{k}$ $\mathrm{n} \quad=$ jumlah sampel, dalam hal ini bernilai 41

$\mathrm{k}=$ jumlah variabel yang digunakan. Dalam hal ini bernilai 2

sehingga derajat bebasnya adalah 39 (41-2). Oleh karena uji t yang dilakukan adalah uji 2 arah maka yang dibaca adalah $t(1 / 20,05)$ atau $t 0,025$.
- $t_{\text {tabel }}$
$=2,02$
- $t_{\text {hitung }}(\mathrm{X})$
$=9,765$

Keputusan:

Variabel Komunikasi Dakwah Majelis Ulama Indonesia (X)

- Oleh karena $t_{\text {hitung }}>\mathrm{t}_{\text {tabel }}$ maka Ho ditolak, artinya Komunikasi Dakwah Majelis Ulama Indonesia berpengaruh secara nyata (signifikan) terhadap Kepatuhan Umat Islam

persamaan regresinya adalah:

$$
\hat{\mathbf{Y}}=\mathbf{2 8 , 6 0 9}+\mathbf{0 , 8 4 8 X}
$$

Dimana :

$\hat{\mathrm{Y}}=$ Kepatuhan Umat Islam

$\mathrm{X}=$ Komunikasi Dakwah Majelis Ulama Indonesia

Dari persamaan dapat diuraikan sebagai berikut:

- Setiap kenaikan 1 skor variabel Komunikasi Dakwah Majelis Ulama Indonesia (X) dapat meningkatkan 0,848 skor variabel Kepatuhan Umat Islam.

\section{Pembahasan}

Menghubungkan data hasil penelitian dengan teori komunikasi S-O-R (StimulusOrganism-Response) menunjukkan bahwa stimulus dalam penelitian ini yaitu Majlelis Ulama Indoneisa (MUI) sebagai komunikator yang memberikan pesan kepada umat Islam di Cinere Depok sebagai komunikan. Respon umat Islam yang positif terhadap komunikasi dakwah MUI dan fatwa-fatwa MUI yang berkaiatan dengan wabah covid-19 menunjukkan bahwa stimulus yang diberikan diterima oleh komunikan.

Terdapat dua keahlian penting yang dimiliki oleh Majelis Ulama Indonesia (MUI) sebagai komunikator yaitu memiliki pengetahuan yang luas dan mendalam (kredibel) tentang Al-Qur'an dan Al-Hadits sebagai sumber utama ajaran Islam. Sikap dan sifat ulama MUI yang berani menyatakan kebenaran turut mendukung terhadap keberhasilan komunikasi dakwah MUI terhadap kepatuhan umat Islam dalam melaksanakan fatwafatwa MUI yang berkaiatan dengan wabah covid19.

Begitu pun halnya dengan pesan (materi) yang disampaikan oleh MUI juga dapat diterima oleh responden dengan tanggapan yang positif. Menurut responden mereka telah mengerti dan setuju dengan pesan yang disampaikan oleh MUI. Hal ini karena pesan yang disampaikan merupakan informasi yang mereka butuhkan masyarakat, khusus umat Islam, sebab fatwa-fatwa ini terkait dengan panduan dalam beribadah dalam pandemic covid-19. Menurut individual differences theory menyatakan bahwa khalayak yang secara selektif memperhatikan suatu pesan komunikasi, khususnya apabila bersangkutan dengan kepentingannya, akan sesuai dengan sikapnya, kepercayaannya dan nilainilainya.

Dalam kegiatan komunikasi dakwah ini, MUI menggunakan berbagai media komunikasi yang ada, baik media satu arah maupun dua arah seperti ceramah dan penyuluhan agama dan kesehatan melalui majlis taklim, khutbah Jum'at, khutbah hari raya yaitu idul fitri dan idul adha serta surat kabar. Selain itu, digunakan juga media massa dan media sosial, seperti televisi, radio, whatsapp, facebook dll. Yang tidak kalah pentingnya adalah media teladan yang baik dengan memberikan 
contoh nyata kepada umat Islam terkait pencegahan covid-19. Penyebaran informasi tentang fatwa MUI tidak dapat lepas dari media karena melalui media, pesan-pesan disampaikan dengan mudah dipahami dan lebih menarik. Media juga dapat menghindari kesalahan persepsi, memperjelas informasi, dan mempermudah pengertian.

MUI menggunakan juga metode personal dengan suasana informal dalam berkomunikasi dakwah dengan umat Islam. Metode personal melibatkan komunikasi antara komunikator dan komunikan. Jenis komunikasi ini dianggap paling efektif dalam upaya membentuk sikap, pendapat, perilaku, dan hubungan-hubungan dikarenakan sifatnya yang dialogis berupa percakapan. Hasil penelitian menjelaskan bahwa metode komunikasi dakwah dengan hikmah yaitu memperhatikan situasi kondisi sasaran dakwah dengan menitik beratkan pada kemampuan mereka, sehingga didalam menjalankan fatwa-fatwa MUI, mereka tidak lagi merasa terpaksa atau keberatan. Hal lain yang dilakukan MUI adalah berdiskusi/tukar pikiran dan memberikan nasehat-nasehat atau menyampaikan fatwa-fatwa dengan rasa kasih sayang sehingga dapat menyentuh hati umat.

\section{KESIMPULAN DAN SARAN Simpulan}

Berdasarkan hasil penelitian dan pembahasan yang dilakukan, maka dapat diambil kesimpulan sebagai berikut:

1. Ada pengaruh yang kuat antara komunikasi dakwah Majelis Ulama Indonesia terhadap kepatuhan umat Islam di kecamatan Cinere Depok dalam melaksanakan fatwa-fatwa MUI yang berkaitan dengan wabah covid-19.

2. Kontribusi komunikasi dakwah Majelis Ulama Indonesia terhadap kepatuhan umat Islam di kecamatan Cinere Depok dalam melaksanakan fatwa-fatwa MUI yang berkaitan dengan wabah covid-19.mencapai $71.0 \%$, sedangkan sisanya (29.0\%) tidak dapat diterangkan.

\section{Saran}

Disarankan untuk Majelis Ulama Indonesia untuk lebih membuka kesempatan kepada umat Islam utuk berdiskusi atau bertukar pikiran tekait fatwa-fatwa yang dikeluarkan oleh MUI agar dapat menyentuh hati dan pikiran umat sehingga mereka dapat menjalankan fatwa-fatwa MUI dengan kesadaran dan kepatuhan.

\section{REFERENSI}

Buku :

Effendy, Onong Uchjana (2017), Ilmu, Teori dan Filsafat Komunikasi, Bandung : PT. Citra Aditya Bakti
Hasan, Mohammad (2013), Metodologi pengembangan ilmu dakwah, Surabaya : Pena Salsabila

Kriyantono (2006), Teknik Praktis Riset Komunikasi

,Jakarta : Kencana Prenada Media Group

Muallim, Amir (1997), Ijtihad suatu kontroversi antara teori dan fungsi, Yogyakarta : Titian Ilahi

Munawwir,A.W.(1984) Kamusalmunawwir. Surab aya: Pustaka Progressif

Nata, Abuddin (1993), Al-Qur'an dan Hadits, Jakarta : Raja Grafindo Persada

Kementerian Pendidikan dan Kebudayaan RI, (2016), Kamus Besar Bahasa Indonesia daring, Jakarta, Badan Pengembangan dan Pembinaan Bahasa

Prasetyo, B. (2005), Metode Penelitian Kuantitatif. Jakarta: PT. Raja Grafindo Persada

Rosyada, Dede (1993), Hukum Islam dan Prana Sosial, Jakarta : Raja Grafindo Persada

Shihab, Quraish (1998), Membumikan Al-Qur'an: Fungsi dan Peran Wahyu Dalam Kehidupan Masyarakat, Bandung: Mizan.

Sugiyono (2009), Metode Penelitian Kuantitatif, Kualitatif dan $R \& D$, Bandung : Alfabeta

Tasmara, Toto (1997), Komunikasi Dakwah, Jakarta : Gaya Media Pratama.

\section{Jurnal Ilmiah :}

Ansori, Isa. (2017). Kedudukan fatwa di beberapa negara muslim (Malaysia, Brunei Darussalam, dan Mesir), e-journal Analisis, Universitas Islam Negeri Raden Intan, Lampung

Badi, Ahmad (2013), Ijtihad : teori dan penerapanya, Jurnal pemikiran Islam, Institut Agama Islam Tribakti, Kedir

Fuad, Iwan Zaenul, dkk, (2013), Persepsi dan ketaatan umat Islam terhadap ulama, ejournal penelitian iainpekalongan.ac.id

Hartono (2006), Kepatuhan dan kemandirian santri (analisis psikologis), Jurnal studi Islam dan budaya, Vol.4 No. 1, LPPM IAIN Purwokerto. 
Dicky Salahuddin, dan Afrah Jamilah

MUTAKALLIMIN; Jurnal Ilmu Komunikasi

Vol 3 No 2 November 2020

Kusumadewi, Septi, (2013), Hubungan antara dukungan sosial peer grup dan kontrol diri dengan kepatuhan terhadap peraturan pada remaja puteri pondok pesantren modern Islam Assalam Sukuharjo, Jurnal Ilmiah
E-ISSN : 2686-178X

Psikologi Candrajiwa, Universitas Sebelas Maret

Markarma, A. (2014), Komunikasi dakwah efektif dalam perspektif Al-Qur'an, Hunafa: Jurnal Studia Islamika, LP2M IAIN Palu 